\title{
Post-harvest conservation of organic strawberries coated with cassava starch and chitosan
}

\author{
Raquel P. Campos ${ }^{1}$, Angela Kwiatkowski², Edmar Clemente ${ }^{3}$
}

\begin{abstract}
The strawberry is as non-climacteric fruit, but has a high post-harvest respiration rate, which leads to a rapid deterioration at room temperature. This study aimed to evaluate the application of biodegradable coating on postharvest conservation of organic strawberries, cv. Camarosa, packed in plastic hinged boxes and stored at $10{ }^{\circ} \mathrm{C}$. The treatments consisted of: a) control; b) $2 \%$ cassava starch; c) $1 \%$ chitosan; and d) $2 \%$ cassava starch $+1 \%$ chitosan. Physical and chemical characteristics of fruits were evaluated at 3, 6 and 9 days of storage, and microbiological and sensory analyses were carried out at the end of the storage period. The treatments influenced positively the post-harvest quality of organic strawberries. The coating cassava starch + chitosan provided the best results, with less than $6 \%$ of loss in fruit mass, lower counts of yeast and psychrophilic microorganisms and the best appearance according to the sensory analysis.
\end{abstract}

Key words: Fragaria ananassa Duch., biodegradable coatings, sensory quality.

\section{RESUMO}

\section{Conservação pós-colheita de morangos recobertos com fécula de mandioca e quitosana}

O morango é classificado como fruto não climáterico, mas apresenta taxa respiratória pós-colheita elevada, o que o leva a uma rápida deterioração em temperatura ambiente. Este trabalho teve por objetivo avaliar a aplicação de revestimentos biodegradáveis na conservação pós-colheita de morangos orgânicos, cv. Camarosa, acondicionados em embalagens plásticas e armazenados a $10{ }^{\circ} \mathrm{C}$. Os tratamentos foram: a) controle, b) fécula de mandioca $2 \%$; c) quitosana $1 \%$ e; d) fécula de mandioca $2 \%$ + quitosana $1 \%$. Foram avaliadas as características físicas e químicas dos frutos, aos três, seis e nove dias de armazenamento, e realizadas análises microbiológicas e sensoriais, ao final do armazenamento. Os tratamentos alteraram positivamente a qualidade pós-colheita dos morangos orgânicos. O revestimento que mais se destacou foi fécula de mandioca mais quitosana, apresentando valor inferior a $6 \%$ de perda de massa nos frutos, menor quantidade de leveduras e de micro-organismos psicrotrófilos e melhor aparência na análise sensorial.

Palavras-chave: Fragaria ananassa Duch., revestimentos biodegradáveis, qualidade sensorial.

\footnotetext{
Received 24/05/2010 and accepted for pubication 27/06/2011

${ }_{1}^{1}$ Agronomist engineer, Doctor, Departamento de Agronomia, Universidade Estadual de Maringá, Departamento de Pós-graduação em Agronomia, Av Colombo, 5790, Zona 7, 87020-900, Maringá, PR, Brasil. campos-rp@hotmail.com

${ }^{2}$ Food Technologist, Doctor Science, Universidade Estadual de Maringá, Departamento de Pós-graduação em Agronomia. Av Colombo, 5790, Zona 7, 87020-900, Maringá, Paraná, Brasil. angelak.k@gmail.com

${ }^{3}$ BSc in Chemistry, Doctor. Universidade Estadual de Maringá, Centro de Ciências Exatas, Departamento de Química. Av. Colombo, 5790, Zona 7, 87020-900 Maringá, PR, Brasil. eclemente@uem.br. Corresponding author
}

Rev. Ceres, Viçosa, v. 58, n.5, p. 554-560, set/out, 2011 


\section{INTRODUCTION}

The use of low temperatures helps in increasing the post-harvest storage life and is the basis for complementary methods of preserving fruit, such as controlling or modifying the atmosphere and use of edible films (Santos et al., 2007). There are a number of studies on the use of biodegradable coatings associated with cold storage (Tanada-Palmu \& Grosso, 2005; Park, 2005).

Coatings or coverings control the loss of flavour volatiles, besides regulating the gas exchange with the external environment and water losses (Chitarra \& Chitarra, 2005). Coatings produced from biopolymers have numerous advantages, including being biodegradable while having good mechanical and barrier properties, and helping to improve the appearance and preserve the gustatory and nutritional properties of foods (Villadiego et al., 2005).

Chitosan coating has the potential to prolong storage life and control fruit rots because of its ability to modify the internal atmosphere in tissues and its fungistatic activity, as well as the ability to induce defense mechanisms in plants and fruits against infections caused by a variety of pathogens (No et al., 2007). Several positive effects were obtained with its application to postharvest preservation of strawberry (Han et al., 2005; HernándezMuñoz et al., 2006). In addition, chitosan has excellent biocompatibility/biodegradability, is non toxic and absorbs water (Chiandotti, 2005). The coating produced with cassava starch has good appearance, is bright and transparent, non-toxic and has low cost. Its application to strawberries resulted in decreased mass losses, preservation of texture and longer shelf-life (Henrique \& Cereda, 1999).

The high perishability and high susceptibility to fungal diseases of strawberries point towards the importance of using bioactive substances, such as chitosan, to control postharvest diseases, while their association with cassava starch is a contribution to maintaining the quality of the organic product. The search for clean technologies reflects the concerns facing the global food security and environmental preservation.

Strawberry fruits must be of a high microbiological quality in order to ensure that the consumer does not receive spoilt or disease-carrying fruits. The presence of microorganisms such as mesophilic (grow best at room temperature) and psychrophilic (grow best at low temperatures) bacteria, yeasts and molds, which besides reducing the fruit's shelf life, can transmit pathogens, posing a risk to consumer health (Cenci et al., 2007, Carvalho et al., 2005). Botrytis cinerea, Colletotrichum spp. and Rhizopus sp. are the microorganisms that most commonly attack strawberries (Hilarino, 2009). The strawberry fruit rot (grey mould) caused by Botrytis cinerea develops in any part of the fruit, but is mostly found on the calyx end or on the sides of fruit in contact with other rotten fruit. Anthracnose (black spot), caused by Colletotrichum spp., develops spots that turn dark brown or black and affects most parts of the plant, causing severe losses in production and quality of strawberry. Rhizopus sp. fruit rot is associated with the presence of wounds in the fruit, but may also occur in intact fruit (Ulli \& Macarthur, 2004).

Therefore, this study aimed to evaluate the postharvest quality of organic strawberries, cv. Camarosa, coated either with chitosan, cassava starch or with a combination of chitosan and cassava starch during storage in plastic hinged boxes.

\section{MATERIAL AND METHODS}

Strawberry (Fragaria x ananassa Duch.) fruits, cv. Camarosa, produced in the organic system in Maringá, PR, Brazil, and certified by the Biodynamics Institute, with $75 \%$ of the surface red in color, were used in the experiment. The chitosan used for coating had a degree of deacetylation of $98.18 \%$.

The experiment was arranged in a completely randomized design and consisted of 4 coatings $x 4$ storage times (0, 3, 6 and 9 days), with six replicates. The experimental unit consisted of ten fruits packed per crystal clear (PET - polyethylene terephthalate) hinged box. The parameters evaluated were: mass loss, color development and damage caused by mold or decay.

A total of 20 fruits packed in each hinged plastic box and stored were used in the other analyses. For the chemical analysis, six fruits were disintegrated in a mixer for two minutes, with three replicates per coating. The analyses were repeated twice for each storage time.

After selecting the size, color, shape, degree of maturity and phytosanitary condition, the fruits received the following coatings: a) $2 \%$ cassava starch (CS); b) $1 \%$ chitosan dissolved in solution of $0.6 \%$ ascorbic acid $(\mathrm{AAC}) ; \mathrm{c}) \mathrm{CS}+\mathrm{AAC}(\mathrm{CS}+\mathrm{AAC})$ and d) control without coating (CTL).

The coating produced from cassava starch, at a concentration of $2 \%$, was obtained by stirring the suspension of starch in distilled water under heating, for about 30 minutes at $70{ }^{\circ} \mathrm{C}(\mathrm{CS})$.

The coating produced from chitosan was obtained by dissolving $20 \mathrm{~g}$ in $2 \mathrm{~L}$ of solution acidified with $0.6 \%$ ascorbic acid, by manual stirring for solubilization (AAC).

Both suspensions CS and AAC were mixed together to obtain the treatment of combined coatings (CS+AAC).

The three coating solutions were homogenized in a 4 $\mathrm{L}$ beaker with a mixer for two minutes prior to the immersion 
of 250 fruits per each coating. The fruits remained in these solutions for one minute, giving a slight stir on the surface, and were placed on a nylon mesh screen to drain excess liquid. They were left to dry at room temperature for about three hours, then stored in a BOD chamber at $10{ }^{\circ} \mathrm{C}$ until they remained fit for marketing. Evaluations of mass loss and physical, chemical and sensory analyses were carried out every three days.

\section{Physical analysis}

Mass loss - the experimental units (fruits) were individually weighed in a semi-analytical scale and calculations were performed for each repetition using the equation: mass loss $(\mathrm{g} / 100 \mathrm{~g})=$ (initial mass - final mass/ initial mass) /100.

Color - using the subjective scores from 1 to 4 : grade $1-75 \%$ of fruit surface was red in color; grade $2-75$ to $95 \%$ of fruit surface was red; grade 3 - more than $95 \%$ of fruit surface was red; and grade $4-100 \%$ of fruit surface was intense red. The average of each plot was calculated by multiplying the number of fruits by their respective grade and dividing the sum of this value by the total number of fruits of the plot.

Incidence of rot - was obtained by counting (and then discarding) the fruits with visible symptoms of rot and expressing it as percentage. On the last day of storage the discarded fruits were separated by symptoms of rot caused by different pathogens.

\section{Chemical analysis}

Total soluble solids (TSS) - were determined by using a refractometer, then expressed in ${ }^{\circ} \mathrm{Brix}$ and corrected when the room temperature was above $20^{\circ} \mathrm{C}$ and acidity content of the fruit was above 1\% (Carvalho et al ., 1990).

Total titrable acidity (TTA) - was determined by titration with standardized $\mathrm{NaOH} 100$ mmol.L $\mathrm{L}^{-1}$, using $10 \mathrm{~g}$ of sample diluted in $100 \mathrm{~mL}$ of distilled water and expressed in $\mathrm{g}$ citric acid.100 $\mathrm{g}^{-1}$ of pulp (Carvalho et al., 1990).

Ascorbic acid - was determined by titration, by the reduction of 2,6-dichlorophenol-indophenol-sodium, standardized with ascorbic acid and expressed in $\mathrm{mg}$ ascorbic acid.100g-1 of pulp (Carvalho et al., 1990).

\section{Sensory analysis}

After eight days of storage, healthy fruits were chopped and used for the analysis of aroma, texture and flavor. For evaluation of the overall appearance, eight fruits per coating treatment were kept intact. The 9-point hedonic scale ranged from like extremely (score 9) to dislike extremely (score 1), carried out by a group of 38 untrained tasters to indicate a preference among the fruits, as described by Miller (2005).

\section{Microbiological analysis}

Counts of mesophilic and psychrophilic bacteria and yeasts and molds were performed using $25 \mathrm{~g}$ of strawberries disintegrated for each analysis and inoculated in serial dilutions $\left(10^{-1}, 10^{-2}\right.$ and $\left.10^{-3}\right)$ with duplicate plate counts for each dilution, following the methodology of FDA/AOAC (1995).

\section{Statistical analysis}

Data were analyzed by the analysis of variance (ANOVA) and means of each variable tested were compared by the Scott-Knot test at 5\% probability level, according to Ramalho et al. (2000), using the software SISVAR (University of Lavras, MG, Brazil).

\section{RESULTS AND DISCUSSION}

Fruit mass loss was significant among the treatments over the periods of three, six and nine days. Throughout the storage period, the treatment $2 \%$ cassava starch with $1 \%$ chitosan $(\mathrm{CS}+\mathrm{AAC})$ resulted in the lowest fruit mass loss, reaching $6.13 \%$ at nine days, and was significantly different from the other treatments and the control, which ranged between 8.45 and $9.40 \%$ (Table 1). The maximum acceptable mass loss for strawberries is $6 \%$, to prevent depreciation in the fruit external appearance (Cantillana, 2003).

The barrier to water loss imparted by the plastic boxes, without ventilation holes, in association with the lower post-harvest handling of fruits of the control treatment provided mass loss similar to that found in the treatments with cassava starch (CS) and chitosan (AAC). HernándezMuñoz et al. (2006) found that $1.5 \%$ chitosan dissolved in $0.5 \%$ acetic acid used as coating for strawberries cv. Camarosa, at $20{ }^{\circ} \mathrm{C}$ for four days, resulted in lower fruit mass loss. But in this study, the use of $1 \%$ chitosan did not provide good results (Table 1), possibly because of the lower concentration used and the type of acid used for dissolving it.

The average grade for the initial fruit color, after setting up the experiment, was close to 3, which shows the rapid advancement of red color development of grade-1 fruits (75\% fruit surface red) (Table 1). At three days of storage, the mean ratings for color of fruits showed no significant differences among the coating treatments. At the end of nine days, the fruits from the control showed a mean rating of fruit color of 3.60, which was significantly higher than those of the treatments CS, AAC and CS+AAC, with ratings between 3.36 and 3.21. Color preservation by chitosan was also reported by Hernández-Muñoz et al. (2006) in strawberries cv. Camarosa and by Scanavaca Junior (2007) in mango cv. Surpresa coated with cassava starch. However, Ribeiro et al. (2007) found no significant 
Table 1. Means of mass loss and color of fruit surface for organic strawberries, cv Camarosa

\begin{tabular}{|c|c|c|c|c|c|c|c|}
\hline \multirow{2}{*}{ Treatment } & \multicolumn{3}{|c|}{ Mass loss $(\%)$} & \multicolumn{4}{|c|}{ Color (ratings 1-4) } \\
\hline & 3 days & 6 days & 9 days & 0 day & 3 days & 6 days & 9 days \\
\hline CTL & $2.10 \mathrm{aA}^{*}$ & $4.36 \mathrm{aB}$ & $8.45 \mathrm{aC}$ & $3.00 \mathrm{aD}$ & $3.18 \mathrm{aC}$ & $3.35 \mathrm{aB}$ & $3.60 \mathrm{aA}$ \\
\hline CS & $2.81 \mathrm{aA}$ & $5.27 \mathrm{aB}$ & $9.14 \mathrm{aC}$ & $2.88 \mathrm{aC}$ & $3.10 \mathrm{aB}$ & $3.23 \mathrm{aA}$ & $3.36 \mathrm{bA}$ \\
\hline $\mathrm{AAC}$ & $2.72 \mathrm{aA}$ & $4.86 \mathrm{aB}$ & $9.40 \mathrm{aC}$ & $2.88 \mathrm{aB}$ & $3.10 \mathrm{aA}$ & $3.28 \mathrm{aA}$ & $3.25 \mathrm{bA}$ \\
\hline $\mathrm{CS}+\mathrm{AAC}$ & $1.53 \mathrm{bA}$ & $3.99 \mathrm{bB}$ & $6.13 \mathrm{bC}$ & $2.93 \mathrm{aB}$ & $3.18 \mathrm{aA}$ & $3.24 \mathrm{aA}$ & $3.21 \mathrm{bA}$ \\
\hline
\end{tabular}

* Means followed by the same letter are not significantly different $(\mathrm{p} \leq 0.05)$; small letters in the column of treatments; and capital letters in the line of days of storage. $(\mathrm{n}=6)$.

Treatments: Control (CTL); coating with $2 \%$ cassava starch (CS); $1 \%$ chitosan (AAC); $2 \%$ cassava starch $+1 \%$ chitosan $(\mathrm{CS}+\mathrm{AAC})$; stored at $10 \pm 1{ }^{\circ} \mathrm{C}$ and $60 \pm 5 \% \mathrm{RH}$

differences for color development between coated and uncoated strawberry fruits using different compositions of starch, carrageenan and chitosan, as well as Del-Valle et al. (2005) using cactus mucilage.

The incidence of fruit rot started on day 3 of cold storage, in the treatments AAC and CS+AAC (Figure 1A). The diseases that appeared on the fruits were anthracnose (black spot) (Colletotrichum sp.) and Rhizopus fruit rot (Rhizopus sp.), which are among the major fruit rot of strawberries (Costa et al., 2003).

The incidence of fruit rot on day 9 of cold storage was significantly higher in fruits coated with cassava starch, approximately $65 \%$, while the other coatings were around $50 \%$ (Figure 1B). The lower incidence of post-harvest diseases on CTL fruits is probably because they have not been washed, while the increased moisture in the coated fruits may have favored the spread of anthracnose and
Rhizopus rot during storage. But, the advance of the anthracnose fungus growth was delayed by the use of coatings, as the number of spots with spores decreased in relation to the control (Figure 1B). The marked reduction in decay of strawberries coated with chitosan reported by Reddy et al. (2000) and Hernández-Muñoz et al. (2006), and at pre-harvest by Mazaro et al. (2008), was not found in this study. However, the grey mould (Botrytis cinerea), which was the main rot controlled by the chitosan coating, as verified by these authors, did not occur in this experiment.

There was no significant difference for the content of total soluble solids (TSS) throughout the refrigerated storage of strawberry fruits, ranging from $6.85^{\circ} \mathrm{Brix}$ (CTL) to $7.80^{\circ} \mathrm{Brix}$ (CS+AAC), with initial content of $7.46^{\circ} \mathrm{Brix}$ (Figure 2A). Accordingly, Malgarim et al. (2006a) reported mean initial content of $7.35^{\circ} \mathrm{Brix}$ in fruits of $\mathrm{cv}$. Camarosa,
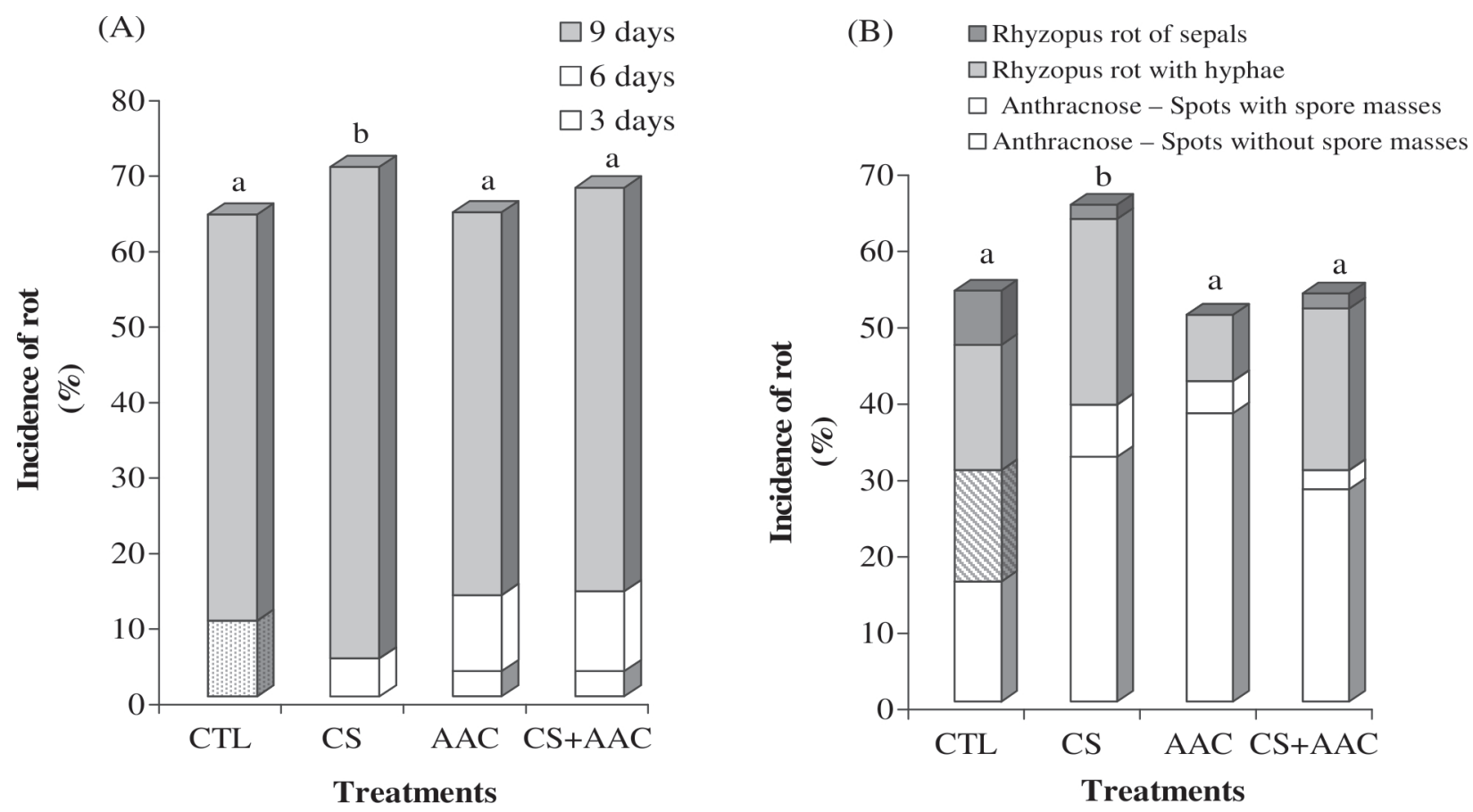

Figure 1. Incidence of rot in organic strawberries cv. Camarosa. Control (CTL); coating with $2 \%$ cassava starch (CS); $1 \%$ chitosan (AAC); $2 \%$ cassava starch $+1 \%$ chitosan $\left(\mathrm{CS}+\mathrm{AAC}\right.$ ); during storage at $10 \pm 1{ }^{\circ} \mathrm{C}$ and $60 \pm 5 \% \mathrm{RH}$. (A) Incidence at days 3,6 and 9. (B) Incidence at day 9 separated by type of rot. 
with variations in content values having no relation with the treatments or storage periods.

The total titratable acidity (TTA) of fresh fruit was $1.03 \mathrm{~g}$ citric acid. $100 \mathrm{~g}^{-1}$ of pulp, which was significantly different from the measurements at day 9 of storage: 1.22 for CS+AAC and CTL and $1.24 \mathrm{~g}$ citric acid.100 $\mathrm{g}^{-1}$ of pulp for AAC, which were significantly different from CS, with $1.27 \mathrm{~g}$ citric acid.100 $\mathrm{g}^{-1}$ of pulp (Figure 2B). These results are in agreement with those previously reported by Campos et al. (2009), with increased acidity in organic strawberries 'Camarosa' coated with cassava starch.

In general, the content of organic acids decreases with fruit ripening, as they are used as respiratory substrate or are converted into sugars (Chitarra \& Chitarra, 2005). Moreover, phenolic compounds also have acidic character and may somehow contribute to the acidity in the pulp. Increased acidity can also be related to the release of galacturonic acids, which accelerate fruit ripening by the action of the enzymes pectinmethylesterase and polygalacturonase (Arriola et al., 1980). Malgarim et al. (2006a) reported TTA of $0.6 \mathrm{~g}$ citric acid $100 \mathrm{~g}^{-1}$ of pulp on fresh strawberries cv. Camarosa; as discussed by the authors, this lower acidity may be due to different conditions of cultivation as well as soil and climate characteristics.

The initial mean content of vitamin $\mathrm{C}$ in the fruits was $44.05 \mathrm{mg}$ of ascorbic acid. $100 \mathrm{~g}^{-1}$ of pulp. But, over the period of cold storage, vitamin $\mathrm{C}$ reduced significantly in CTL fruits; remained the same in CS fruits and increased significantly in fruits coated with AAC and CS+AAC, reaching 49.49 and $57.35 \mathrm{mg} 100 \mathrm{~g}^{-1}$ ascorbic acid., respectively (Figure 2C). The increase in vitamin $\mathrm{C}$ in the treatments coated with chitosan resulted from the addition of $0.6 \%$ ascorbic acid used for its solubilization. Reduction in the ascorbic acid content was also reported during
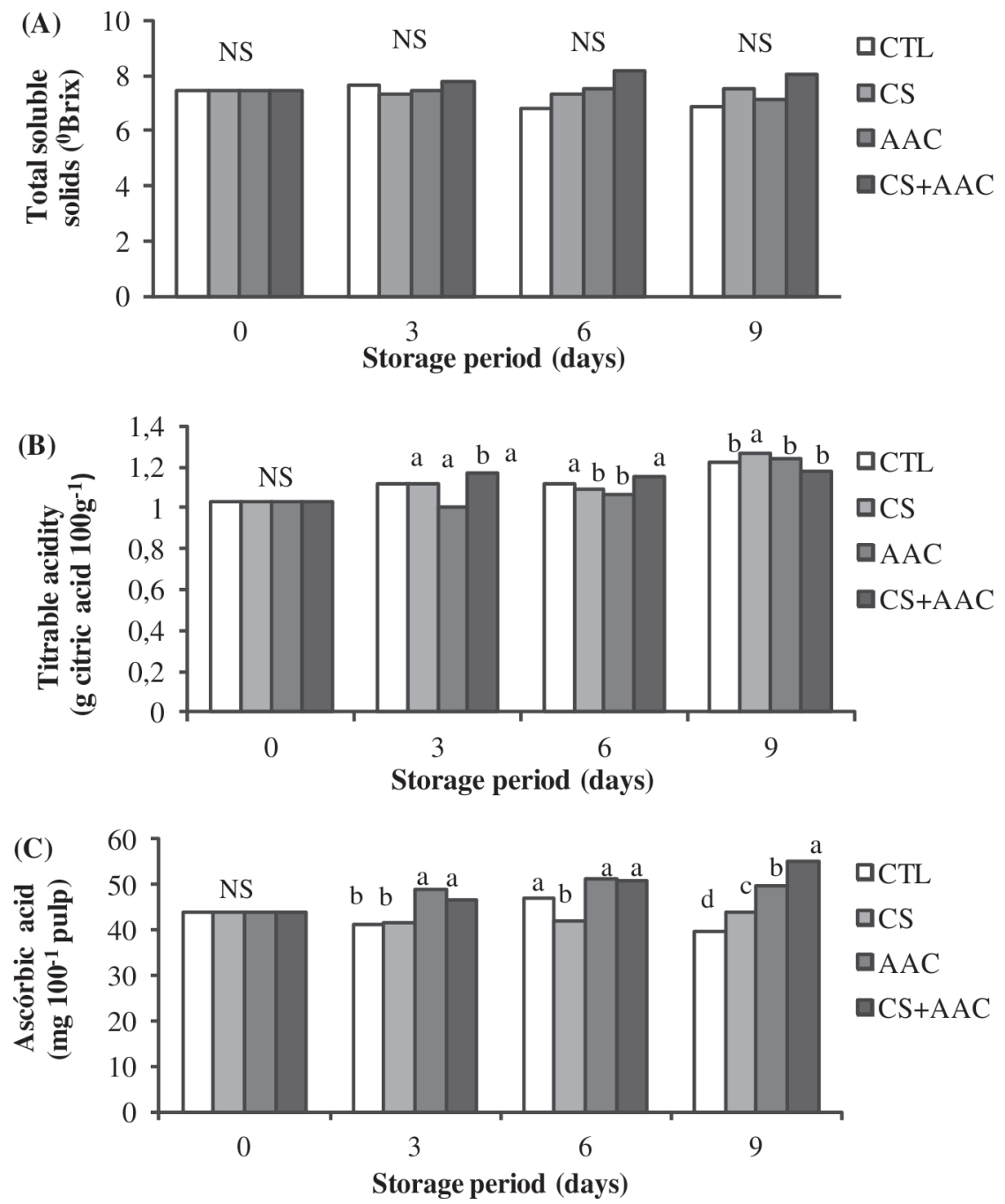

Figure 2. Total soluble solids (A), tritable acidity (B) and ascorbic acid (C) in organic strawberries cv. Camarosa. Control (CTL); coating with $2 \%$ cassava starch (CS); $1 \%$ chitosan (AAC); $2 \%$ cassava starch $+1 \%$ chitosan $(\mathrm{CS}+\mathrm{AAC})$; stored at $10 \pm 1{ }^{\circ} \mathrm{C}$ and 60 $\pm 5 \%$ RH. $(\mathrm{NS}=$ not significantly $(\mathrm{p} \leq 0.05))$. 
storage of strawberry cv. Osogrande (Calegaro et al., 2002), and in strawberries cv. Camarosa packed in polyethylene film (Malgarim et al., 2006b).

In the sensory analysis, no differences were found for the attributes aroma, texture and flavor among the coating treatments, as indicated by the ratings close to 6 (like slightly) and 7 (like moderately) in the hedonic scale, after eight days of storage at $10^{\circ} \mathrm{C}$ (Figure 3). The invariability of sensory attributes in post-harvest strawberry was also reported by Santos et al. (2007).

The appearance of the CTL fruits was graded with ratings below 5 (neither like nor dislike), whereas the treatments with coatings enhanced fruit appearance: CS+AAC was statistically different from the other treatments, resulting in mean ratings between 6 (like slightly) and 7 (like moderately). These results are in agreement with those reported by Han et al. (2005), in which the appearance of fresh strawberries coated with chitosan-based edible coatings was rated at 6.36 .

Fresh fruit had low initial microorganism counts, with marked growth during storage, especially of yeasts, which reached the highest counts in the CTL treatment $\left(10^{5} \mathrm{CFU} /\right.$ g pulp). However, yeast counts were reduced by the treatments $\mathrm{CS}$ and $\mathrm{CS}+\mathrm{AAC}$, which also reduced counts of psychrophiles (Figure 4). Similar reduction in psychrophilic microorganisms and yeasts and molds were obtained by Mali \& Grossmann (2003) in strawberries cv. Dover coated with yam starch-based films, and Campos et al. (2009) in strawberries cv. Camarosa coated with cassava starch associated with Copaiba oil.

Coating with $1 \%$ chitosan reduced the growth rate of microorganisms in strawberries (Ribeiro et al., 2007). Likewise, chitosan associated with potassium sorbate also controlled the growth of Rhizopus sp. and Cladosporium sp., as well as coliforms and aerobic microorganisms during cold storage (Park et al., 2005). Chitosan films were also reported to inhibit the growth of fungi and yeasts in the area of contact, forming a halo of inhibition on the plates inoculated (Casariego, 2004). These findings differ from the result obtained in this study with the use of chitosan alone, possibly because the concentration and type of acid used, and point toward the need for further investigation into the use of these coatings on the postharvest quality of organic strawberries.

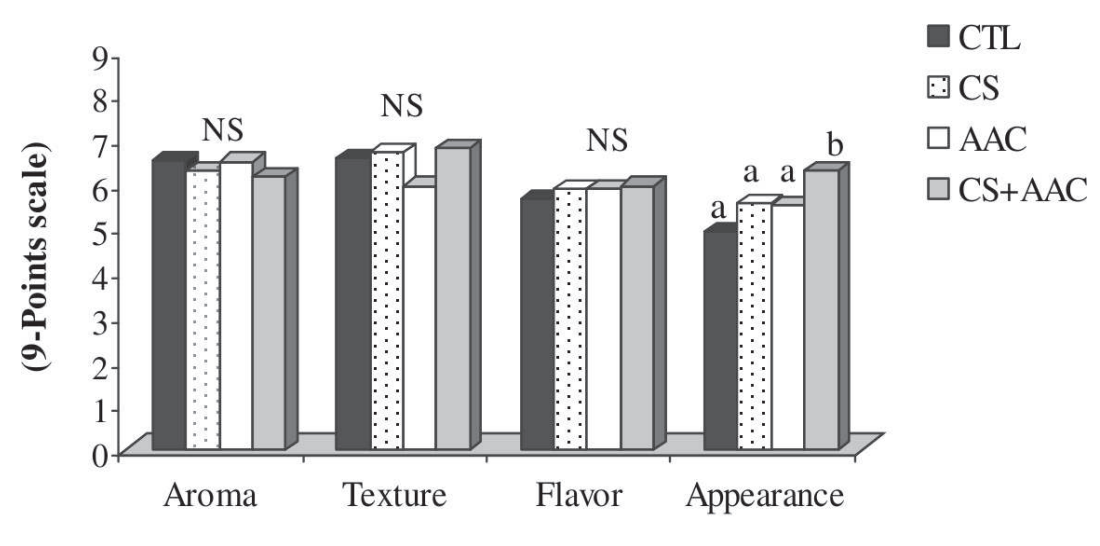

Attributes

Figure 3. Sensory analysis of organic strawberry cv. Camarosa. Control (CTL); coating with $2 \%$ cassava starch (CS); $1 \%$ chitosan (AAC); $2 \%$ cassava starch $+1 \%$ chitosan $(\mathrm{CS}+\mathrm{AAC})$ at day 8 of storage at $10 \pm 1{ }^{\circ} \mathrm{C}$ and $60 \pm 5 \% \mathrm{RH}$. $(\mathrm{n}=38)$. (NS $=$ not significantly (p d" 0.05)).

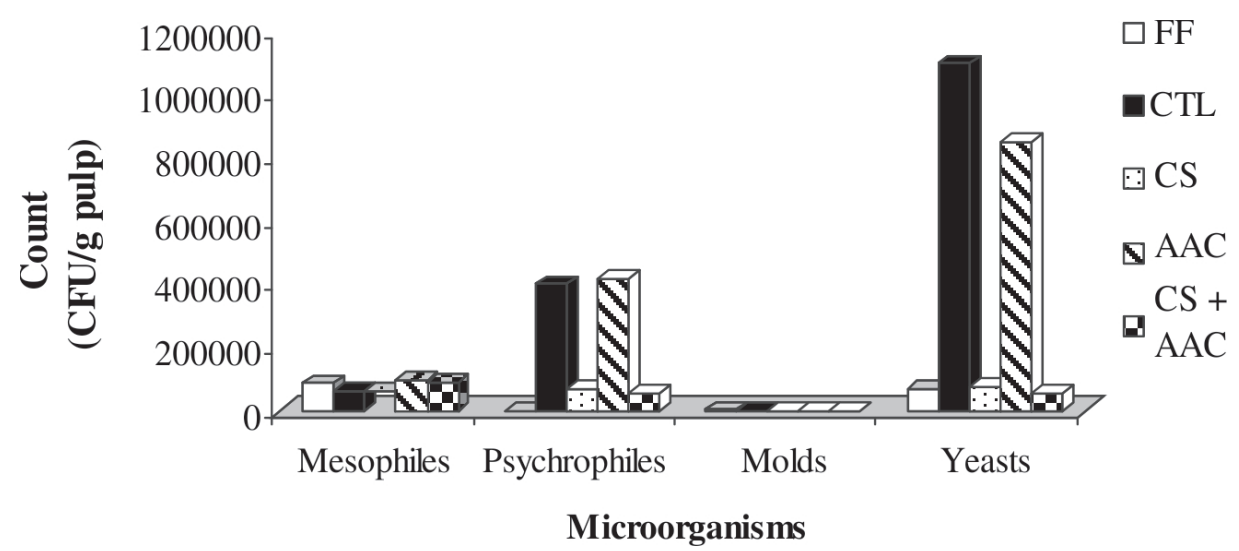

Figure 4. Microorganism counts in organic strawberry, cv. Camarosa. Fresh Fruit (FF); control (CTL); coating with $2 \%$ cassava starch (CS); $1 \%$ chitosan (AAC); $2 \%$ cassava starch + $1 \%$ chitosan (CS + AAC); at day 9 of storage at $10 \pm 1{ }^{\circ} \mathrm{C}$ and $60 \pm 5 \% \mathrm{RH}$. 


\section{CONCLUSIONS}

Coating with cassava starch in association with chitosan enhanced the postharvest conservation of coldstored strawberry, provided reductions in mass loss and counts of psychrophilic microorganisms and yeasts and molds, and improved the appearance of fruits at the end of nine days of cold storage.

\section{ACKNOWLEDGEMENTS}

The authors would like to thank CAPES for granting a doctoral scholarship.

\section{REFERENCES}

Arriola MC, Calzada JF, Menchu JF, Rolz C \& Garcia R (1980) Papaya. In: Tropical and subtropical fruits. Westport, Connecticut, The AVI Publishing Co. Inc. p.316-340.

Calegaro JM, Pezzi E \& Bender RJ (2002) Utilização de atmosfera modificada na conservação de morangos em pós-colheita. Pesquisa Agropecuária Brasileira, 37:1-6.

Campos RP, Rodovalho M \& Clemente E (2009) Coating on 'Camarosa' organic strawberries stored at low temperature. Brazilian Journal of Food Technology, 12:60-67.

Cantillano RF (2003) Colheita e pós-colheita. In: Santos AM \& Medeiros ARM (Ed.). Morango: produção. Brasília, EMBRAPA. p.68-74. (Frutas do Brasil, 40).

Carvalho ACFB, Cortez ALL, Salotti BM, Bürger KP \& VidalMartins AMC (2005) Presença de micro-organismos mesófilos, psicrotróficos e coliformes em diferentes amostras de produtos avícolas. Arquivo do Instituto de Biologia, 72:303-307.

Carvalho CRL, Mantovani DMB, Carvalho PRN \& Moraes RM (1990) Análises químicas de alimentos. Campinas, Instituto de Tecnologia de Alimentos. 120p.

Casariego A (2004) Obtención de películas antimicrobianas a partir de quitosana. Ciência y Tecnologia de los Alimentos, 14:1114.

Cenci SA, Freitas-Silva O, Vaz SG, Rocha GO, Regis SA \& Cunha FQ (2007). Etapas do processamento mínimo do morango. Rio de Janeiro, EMBRAPA. 4p. (Comunicado Técnico, 110).

Chiandotti RS. (2005) Síntese e propriedades de derivados de quitosana lauroil quitosana. Dissertação de Mestrado, Universidade Federal do Paraná, Curitiba, 59p.

Chitarra MIF \& Chitarra AB (2005) Pós-colheita de frutos e hortaliças: Fisiologia e manuseio. $2^{\mathrm{a}}$ edição. Lavras, UFLA. 785p.

Costa H, Zambolim L \& Ventura JA (2003) Manejo integrado das doenças do morangueiro. In: Zambolim, L (Ed.). Manejo integrado; produção integrada; fruteiras tropicais; doenças e pragas. Viçosa, UFV. p. 131-149.

Del-Valle V, Hernández-Munoz P, Guarda A \& Galotto MJ (2005) Development of a cactus-mucilage edible coating (Opuntia fícus indica) and its application to extend strawberry (Fragaria ananassa) shelf-life. Food Chemistry, 91:751-756.

FDA/AOAC (1995) Food and Drug Administration/Association Official Methods Bacteriological analytical manual. 8.ed. Gaitherberg: FDA-AOAC.

Han C, Lederer C, Mcdaniel M \& Zhao Y (2005) Sensory evaluation of fresh strawberries (Fragaria ananassa) coated with chitosanbased edible coatings. Jounal Food Science, 70:172-178.
Henrique CM \& Cereda MP (1999) Utilização de biofilmes na conservação pós-colheita de morango (Fragaria ananassa Duch) cv IAC Campinas. Ciência e Tecnologia de Alimentos, 19:231233.

Hernández-Muñoz P, Almenar E, Ocio MJ \& Gavara R (2006) Effect of calcium dips and chitosan coatings on postharvest life of strawberries (Fragaria x ananassa). Postharvest Biology and Technology, Amsterdam, 39:247-253.

Hilarino MPA (2009) Avaliação in vitro e in vivo do uso potencial de fungos endofíticos como agentes de controle biológico de doenças do morangueiro causadas por fungos fitopatogênicos. Dissertação de Mestrado. Universidade Federal de Minas Gerais, Belo Horizonte. 73 p.

Malgarim MB, Cantillano RFF \& Coutinho EF (2006a) Sistemas e condições de colheita e armazenamento na qualidade de morango 'Camarosa'. Revista Brasileira de Fruticultura, 28:185-189.

Malgarim MB, Tibola CS, Zaicovski CB, Ferri VC \& Silva PR (2006b) Modificação da atmosfera e resveratrol na qualidade pós-colheita de morangos 'Camarosa'. Revista Brasileira Agrociência, 12:67-70.

Mali S \& Grossmann MVE (2003) Effects of yam starch films on storability and quality of fresh strawberries (Fragaria ananassa). Journal of Agricultural and Food Chemistry, 51:7005-7011.

Mazaro SM, Deschamps C, Mio LLM, Biasi LA, Gouvêa A \& Sautter CK (2008) Comportamento pós-colheita de frutos de morangueiro após a aplicação pré-colheita de quitosana e acibenzolarsimetril. Revista Brasileira de Fruticultura, 30:185-191.

Monteiro ARG (2005) Introdução à análise sensorial de alimentos. Maringá, Eduem. 46p.

No HK, Meyers SP, Prinyawiwatkul W \& Xu Z (2007) Applications of chitosan for improvement of quality and shelf life of foods: a review. Journal Food Science, 72:87-100.

Park S, Stan SD, Daeschel MA \& Zhao Y (2005) Antifungal coatings on fresh strawberry (Fragaria x ananassa) to control mold growth during cold strorage. Journal Food Science, 70:202-207.

Ramalho MAP, Furtado D \& Oliveira AC (2000) Experimentação em genética e melhoramento de plantas. Lavras, UFLA, 324p.

Reddy BMY, Belkacemi K, Corcuff R, Castaigne F \& Arul J (2000) Effect of pre-harvest chitosan sprays on postharvest infection by Botrytis cinerea and quality of strawberry fruit. Postharvest Biology and Technology, 20:39-51.

Ribeiro C, Vicente AA, Teixeira, JA \& Miranda C (2007) Optimization of edible coating composition to retard strawberry fruit senescence. Postharvest Biology and Technology, 44:63-70.

Santos LO, Martins RN, Durigan JF \& Mattiuz B (2007) Técnicas de conservação pós-colheita do morango. Informe Agropecuário, 28:84-87.

Scanavaca Júnior L, Fonseca N \& Pereira MEC (2007) Uso de fécula de mandioca na pós-colheita de manga 'Surpresa'. Revista Brasileira de Fruticultura, 29:067-071.

Tanada-Palmu OS \& Grosso CRF (2005) Effect of edible wheat glúten-based films and coatings on refrigerated strawberry (Fragaria ananassa) quality. Postharvest Biology and Technology, 36:199-208.

Ullio L \& Macarthur E (2004) Strawberry disease control guide. Disponível em: http://www.dpi.nsw.gov.au/_data/assets/pdf_file/ 0011/119558/strawberry-disease-control.pdf. Acessado em 20 jun. 2011.

Villadiego AMD, Soares NFF, Andrade NJ, Puscmann R, Minim VPR \& Cruz, R (2005) Filmes e revestimentos comestíveis na conservação de produtos alimentícios. Revista Ceres, 52:221244.

Rev. Ceres, Viçosa, v. 58, n.5, p. 554-560, set/out, 2011 